animal model of insulin resistance and NIDDM ${ }^{13}$, the number of insulin receptors as well as their tyrosine kinase activity is decreased ${ }^{13}$; we found that the amount of PC-1 in these tissues was raised by 54 and $74 \%$, respectively, compared with controls.

MCF-7 cells, a human breast carcinoma cell line that has been used to investigate insulin action ${ }^{14}$, were transfected with an expression plasmid containing PC-1 complementary DNA. Control cells had a PC-1 activity of $10 \pm 5 \mathrm{nmol} \mathrm{mg} \mathrm{min}^{-1}$, which

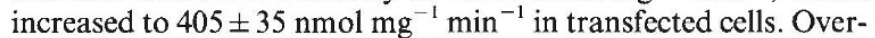
expression of this protein did not alter insulin-receptor binding (Fig. 4a). With PC-1 overexpression, there was marked inhibition of insulin-receptor tyrosine-kinase activity (Fig. $4 b$ ), as measured by both insulin receptor $\beta$-subunit autophosphorylation, and phosphorylation of the intracellular protein, insulin receptor substrate-1 (IRS-1) ${ }^{15}$. In controls, effects of insulin on both functions were observed at $1 \mathrm{nM}$ and were maximal at 10-100 nM. In transfected cells, effects were detected at $10 \mathrm{nM}$ insulin, and at $100 \mathrm{nM}$ the effect of insulin was one-half that of controls. In MCF-7 cells, insulin stimulates $\left[{ }^{3} \mathrm{H}\right.$ ]thymidine incorporation into $\mathrm{DNA}^{14}$ (Fig. $4 c$ ). In control MCF-7 cells, half-maximal stimulation by insulin occurred at concentrations $\sim 8$-fold lower than in cells overexpressing PC-1. We have also observed that $\mathrm{CHO}$ cells transfected with and overexpressing

Received 1 August; accepted 22 November 1994.

1. Reaven, G. M. Diabetes 35, 1595-1607 (1988).

2. Bogardus, C. et al. Diabetes 38, 1423-1432 (1989).

3. Warram, J. H. et al. A. intern. Med. 113, 909-915 (1990)

4. Martin, B. C. et al. Lancet 340, 925-929 (1992).

5. Haring, H. \& Obermaier-Kusser, B. Diabetes Metab. Rev. 5, 431-441 (1989).

6. Taylor, S. I. Diabetes 41, 1473-1490 (1992).

7. Moller, D. E. \& Flier, J. S. New Engl. J. Med. 325, 938-948 (1991).

8. Sbraccia, P. et al. Diabetes 40, 295-299 (1991).

9. Maddux, B. A., Sbraccia, P., Reaven, G. M., Moller, D. E. \& Goldfine, I. D. J. Clin. Endocr. Metab. 77, 73-79 (1993).

10. Buckley, M. F., Loveland, K. A., McKinstry, W. J., Garson, O. M. \& Goding, J. W. J. biol. Chem. 265, 29, 17506-17511 (1990).

11. Funakoshi, 1. et al. Archs Biochem. Biophys. 295, 180-187 (1992).
PC-1 have decreased insulin-receptor tyrosine-kinase activity (unpublished results).

PC-1 is a class II (cytoplasmic amino terminus) membrane glycoprotein; it is the same protein as liver nucleoside pyrophosphatase/alkaline phosphodiesterase I (ref. 16). PC-1 has been detected in other cells, including placenta, chondrocytes, epididymus, kidney tubules, salivary ducts, brain capillaries, skin fibroblasts, myeloma cells, skeletal muscle and fat (ref. 16, and our unpublished results). The size of $\mathrm{PC}-1$ is $115 \mathrm{~K}-135 \mathrm{~K}$, depending on the tissue; $\mathrm{PC}-1$ also exists as a $230 \mathrm{~K}-260 \mathrm{~K}$ dimer. Human PC-1 is predicted to have 873 amino acids, and maps to chromosome 6q22-6q23 (ref. 11). The extracellular domain of PC-1 cleaves phosphosulphate, pyrophosphate and phosphodiesterase linkages. PC-1 may have threonine-specific proteinkinase activity ${ }^{17}$ and is closely associated with the acid fibroblast growth factor receptor ${ }^{17}$; it is regulated by transforming growth factor- $\beta$ (ref. 18).

The function of PC-1 has yet to be identified and so the mechanism by which PC-1 inhibits insulin-receptor tyrosine-kinase activity is only speculation. PC-1 may interact with the insulin receptor to decrease tyrosine-kinase activity, or it may block the insulin-receptor signalling pathway. Further studies will be needed to determine the role of this protein in the insulin resistance of NIDDM.

\title{
Evolution of homeotic gene regulation and function in flies and butterflies
}

\section{Robert W. Warren, Lisa Nagy, Jane Selegue, Julle Gates \& Sean Carroll}

Nature 372, 458-461 (1994)

FIGURE $1 a$ of this Letter is shown below; this panel was omitted from page 459 .

\section{Role of the LIM class homeodomain protein Xlim-1 in neural and muscle induction by the Spemann organizer in Xenopus}

\author{
Masanori Taira, Hiroki Otani, \\ Jean-Plerre Saint-Jeannet \& Igor B. Dawid
}

Nature 372, 677-679 (1994)

THE panels of Fig. $2 b$ of this Letter should have been labelled: left, FITC; middle, 12/101; right, FITC/TR. 